\title{
Microbial Population Dynamics and Exoenzyme Activities in Semidecomposed Organic Substrate Exposed to Low Intensity Colour Lights during Vermicomposting
}

\author{
C.S.K. Mishra, Debayana Priyadarsini and Suryasikha Samal*
}

Department of Zoology, Orissa University of Agriculture and Technology, College of Basic Science and Humanities, Bhubaneswar-751003, India

*Corresponding author

\begin{tabular}{l} 
K e y w o r d s \\
$\begin{array}{l}\text { Low intensity light, } \\
\text { Organic substrate, } \\
\text { Vermicomposting, } \\
\text { Eudrilus engeniae } \\
\text { bacteria, Exoenzymes }\end{array}$ \\
\hline Article Info \\
$\begin{array}{l}\text { Accepted: } \\
10 \text { October } 2018 \\
\text { Available Online: } \\
10 \text { November } 2018\end{array}$ \\
\hline
\end{tabular}

\section{A B S T R A C T}

During vermicomposting, decomposition of organic matter is mostly carried out by the aerobic microbes, facilitated by the earthworms. Light, an important ecological factor can penetrate up to 3-4 cm into surface soil or organic substrates and therefore is expected to influence the biological function of microbes during decomposition. This study reports the effect of low intensity colour lights on microbial population and exoenzyme activities along with changes in certain soil chemical parameters such as $\mathrm{pH}$ and organic carbon in semi-decomposed organic substrate (cattle dung) inoculated with the earthworm Eudrilus eugeniae over an incubation period of 42 days. The results indicated that darkness provide the most suitable environment for maximal bacterial population and activities of the enzymes, invertase, amylase and cellulase. The least population of bacteria was observed in the substrate under white light and red lights whereas blue and green lights indicated relatively higher bacterial population and enzyme activities. The maximal depletion in organic carbon was recorded in substrate in dark and the minimal in white light. Soil pH indicated noticeable decline in the substrate exposed to white and red lights. The study thus indicated that darkness provides the most favourable environment for maximal bacterial growth, exoenzyme activities and percent organic carbon reduction in earthworm inoculated organic substrate.

\section{Introduction}

Microbial population, biomass and activities determine the rate of decomposition of organics and consequently fertility of soil by regulating bioavailability of nutrients. A number of ecological factors influence soil microbial population and enzyme activities (Liu et al., 2008; Araujo et al., 2009). Exoenzymes, chiefly excreted by microorganisms in soil and organic substrates play a vital role in decomposition and nutrient cycling (Pavel et al., 2004; Shi et al., 2006). Temperature and moisture have been considered to be important limiting factors to influence microbial growth and metabolism during decomposition ( $\mathrm{Li}$ and Sarah, 2003). Information are very limited on how visible light could influence bacterial growth and activities (Lucca et al., 2012; Kamel et al., 2016) in soil and other organic 
substrates. Since light can penetrate up to 3-4 $\mathrm{cm}$ in soil, it is likely to certain extent influence the soil biota especially those which thrive in the surface region.

It is known that UV light kills bacteria, but the bactericidal effects of UV may not be unique since recent studies indicate that visible light also produces a somewhat similar effect. The $405 \mathrm{~nm}$ light wave length produce a dose dependent bacterial effect on Pseudomonas aenuginosa and Staphylococcus aureus at about $95.1 \%$ and nearly $90 \%$ rate. The $470 \mathrm{~nm}$ light effectively killed $P$. aenugina at all dose level but killed $S$. aureus at $10-15 \mathrm{~cm}^{2}$ (Guffey et al., 2006, Todars, 2012). Fontana et al., (2015) reported the effect of light on bacterial growth and reported that certain bacteria need light to grow and survive. Many bacteria harbour sufficiently high concentration of endogenous photo synthesizers which are destroyed by intensive irradiation with visible light especially by violet and blue light of wavelength $405 \mathrm{~nm}$ and 470nm (Ashkenazi et al., 2003; Guffey and Willborn, 2006; Maclean et al., 2008). The irradiation at $625 \mathrm{~nm}$ (Red light) did not affect $S$. aureus, E.coli, and $P$. gingivalis, whereas wavelength of $425 \mathrm{~nm}$ (Blue) and 525nm (Green) had deleterious effects. $S$ aureus can get killed at 525nm (Kim et al., 2013).

Mueller et al., (2010) reported that inactive compounds like auto fluorescent proteins can absorb visible day light (500-700nm) and can emit active electrons producing reactive oxygen species (ROS) leading to an increase in photo killing processes in bacteria. Kamel et al., (2016) examined the influence of noncoherent polarized light upon growth of bacteria $S$. aureus, E. coli, $P$ aeruginosa and found that blue and green spectra reduced the growth of the bacteria relative to other colours. Therefore it is apparent that different colour lights have variable impact on bacterial growth and metabolism.
Vermicomposting of organic substrates is conventionally carried out in dark with the epigeic earthworms Eudrilus eugeniae and Eisenia fetida. No information is available on the bacterial activity in the substrate in response to light exposure. Therefore the present study was undertaken to observe the effects of low intensity colour lights on the bacterial population and certain exoenzyme activities in semidecomposed cattle dung. The changes in $\mathrm{pH}$ and percent organic carbon during vermicomposting were also assessed.

\section{Materials and Methods}

Eudrilus eugeniae was procured from the vermiculture unit of Government Quality Control Laboratory, Bhubaneswar, India. The worms were acclimatized in semi-decomposed cattle dung taken in rectangular earthen pot (40 cms $\times 40 \mathrm{cms})$ in dark for 7 days. Five treatment pots of size $(30 \mathrm{cms} \times 30 \mathrm{cms})$ in triplicate were labelled as T1 (Dark), T2 (White), T3 (Blue), T4 (Green), T5 (Red) respectively and each pot was filled with $1 \mathrm{~kg}$ of semi decomposed cattle dung. Twenty clitellated earthworms of identical size were transferred to each treatment pot. Thermo cool sheets were used to cover the pots. The moisture level in the substrate was maintained at $40-50 \%$ by intermittent sprinkling of distilled water. LED lights (0.5 watt) of white, blue, green and red colours were fixed at the center on the inner side of the thermocool sheets for treatments T2 toT4. T1 was taken as control with no light provision. Substrate samples were collected from $3-4 \mathrm{~cm}$ depth from each pot at an interval of 7 days for chemical and microbiological and enzymatic studies. The $\mathrm{pH}$ of the samples was measured by a digital $\mathrm{pH}$ meter (Systronics). Organic carbon (OC) and organic matter (OM) were measured as per Walkley and Black (1934). Bacteria were isolated by serial dilution and spread plate method (Parkinson et al., 1971). The activities of amylase, invertase and 
cellulase were measured as per Ross and Robert (1970). Statistical analysis of data was done for ANOVA using SPSS 6.0 software.

\section{Results and Discussion}

The percent change in $\mathrm{pH}$, organic carbon and total organic matter have been depicted in Figure 1a. Changes in the microbial population and enzyme activities with respect to the control have been presented in Figure $1 \mathrm{~b}$ to $1 \mathrm{e}$. The highest percent increase in $\mathrm{pH}$ $(1.8 \%)$ of the substrate was observed in $\mathrm{T} 1$ and the highest decrease $(6.5 \%)$ in T2. Soil $\mathrm{pH}$ ranged from 7.61 on the $42^{\text {nd }}$ day in $\mathrm{T} 1$ to 5.94 on $28^{\text {th }}$ day in T2. Statistical analysis indicated non-significant variation in the substrate $\mathrm{pH}$ between different colour light exposures over the experimental period. The maximum decrease $(63.88 \%)$ in OC in the substrate was observed in $\mathrm{T} 1$ followed by $50 \%$ in $\mathrm{T} 2$. The highest OC $(5.6 \mathrm{~g} / \mathrm{kg})$ was noted on the $42^{\text {nd }}$ day of T5 and lowest $(1.3 \mathrm{~g} / \mathrm{kg}) \mathrm{OC}$ on the same day in $\mathrm{T} 1$. The highest $(9.65 \mathrm{~g} / \mathrm{kg}) \mathrm{OM}$ was recorded on $42^{\text {nd }}$ day in T5 and the lowest $(2.24 \mathrm{~g} / \mathrm{kg}) \mathrm{OM}$ on the same day in $\mathrm{T} 1$. Statistical analysis indicated non-significant variation in $\mathrm{OC}$ and $\mathrm{OM}$ of the substrate between treatments.

The maximum percent increase in bacterial population (96\%) was observed in T1. The maximum decrease $(34.11 \%)$ was observed in $\mathrm{T} 2$. The colony forming units (CFU) ranged from $25-49 \times 10^{4} \mathrm{CFU} / \mathrm{g}$ soil and was highest on $14^{\text {th }}$ day in T3. The lowest microbial population was observed in T5. Statistical analysis did not indicate significant variation in the microbial population between treatments.

For exoenzyme activities, the maximum percent increase in amylase activity was observed in T1 $(75.92 \%)$ during the experimental period. The enzyme activity decreased by $18.18 \%$ in $\mathrm{T} 2$ over the period.
The enzyme activities in T3 and T4 did not show appreciable variations. The highest amylase activity $(0.190 \mathrm{mg}$ glucose/g soil/h) was observed on the $42^{\text {nd }}$ day in $\mathrm{T} 1$ and lowest $(0.074 \mathrm{mg}$ glucose $/ \mathrm{g}$ soil $/ \mathrm{h})$ on the $1^{\text {st }}$ day in T1. Cellulase activity indicated maximum increase of $24 \%$ in $\mathrm{T} 1$. The enzyme activities decreased by $15 \%$ in $\mathrm{T} 2$ over the experimental period. The highest cellulase activity $(0.087$ mg glucose/g soil/h) was observed on the $42^{\text {nd }}$ day in $\mathrm{T} 1$ and lowest $(0.048 \mathrm{mg}$ glucose $/ \mathrm{g}$ soil/h) on this day in T2. T3 and T4 did not show much variations. Invertase activity varied between treatments. The highest (7.4\%) increase in the enzyme activity was observed in T1. The enzyme activity decreased by $16 \%$ in T2. The highest invertase activity (2.693 $\mathrm{mg}$ glucose/g soil/h) was noted on the $42^{\text {nd }}$ day in $\mathrm{T} 1$ and lowest $(1.978 \mathrm{mg}$ glucose/g soil/h) on the $21^{\text {st }}$ day in T1. Statistical analysis of data indicated non-significant variation in the activities of the enzymes between treatments.

In the present study variations were observed in the bacterial population and exoenzyme activities in the organic substrate exposed to different low intensity light colours and it was observed that white light exerted the maximum inhibitory effect on bacterial growth and enzyme activities relative to other colour lights and darkness. Guffey et al., (2006) have reported that the $405 \mathrm{~nm}$ light produce a dose dependant bactericidal effect on $P$ aenuginxa and $S$ aureus. They also observed that different wave lengths of light had differential effects on certain bacteria. For example, $470 \mathrm{~nm}$ light effectively killed $P$. aenugina at all doses but killed $S$, aureus at $10-15 \mathrm{Jcm}^{2}$.conditions. Fontana et al., (2015) observed that blue light eliminates the black pigments in Porphyromonas gingivalis and has inhibitory effects on these bacteria. The results obtained in the present study support the earlier findings that light inhibits bacterial activity and darkness favours bacterial growth and multiplication. 


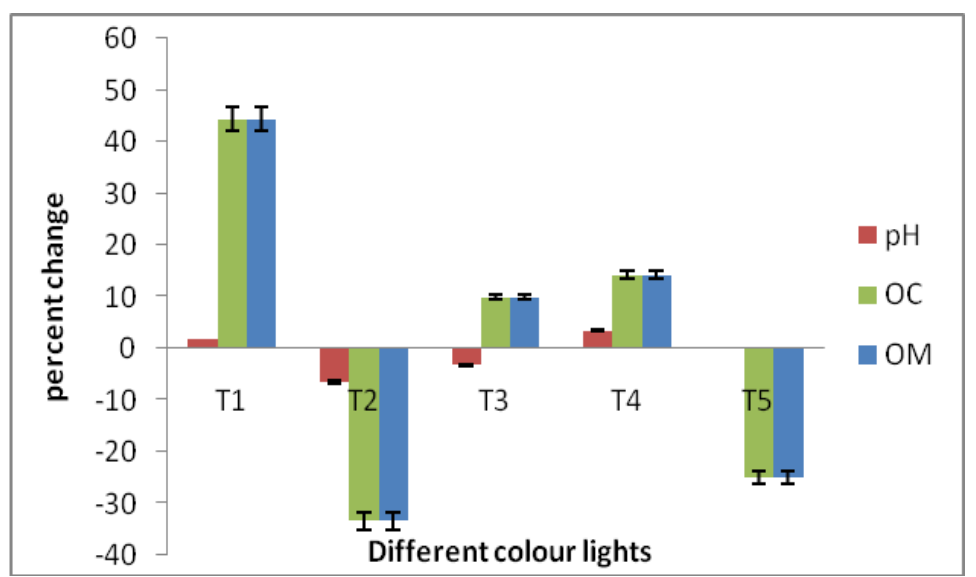

$\mathbf{a}$

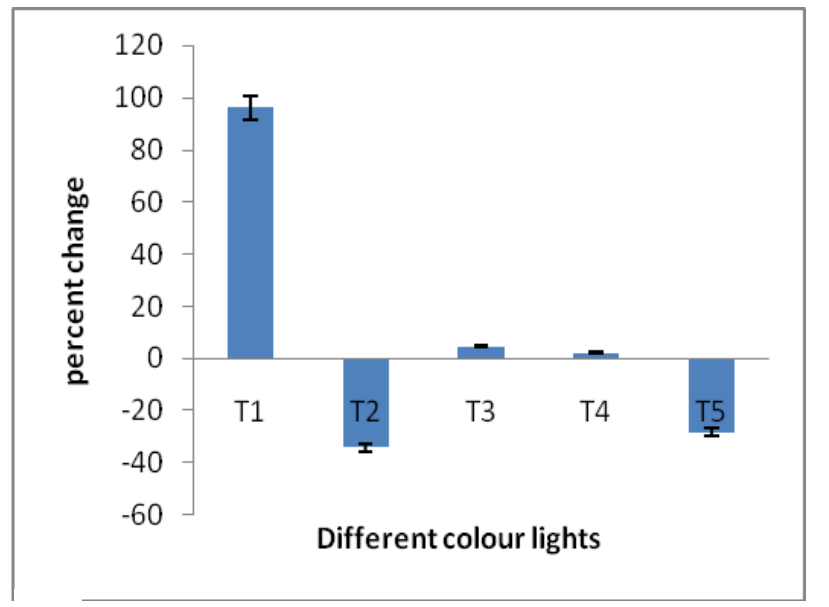

b
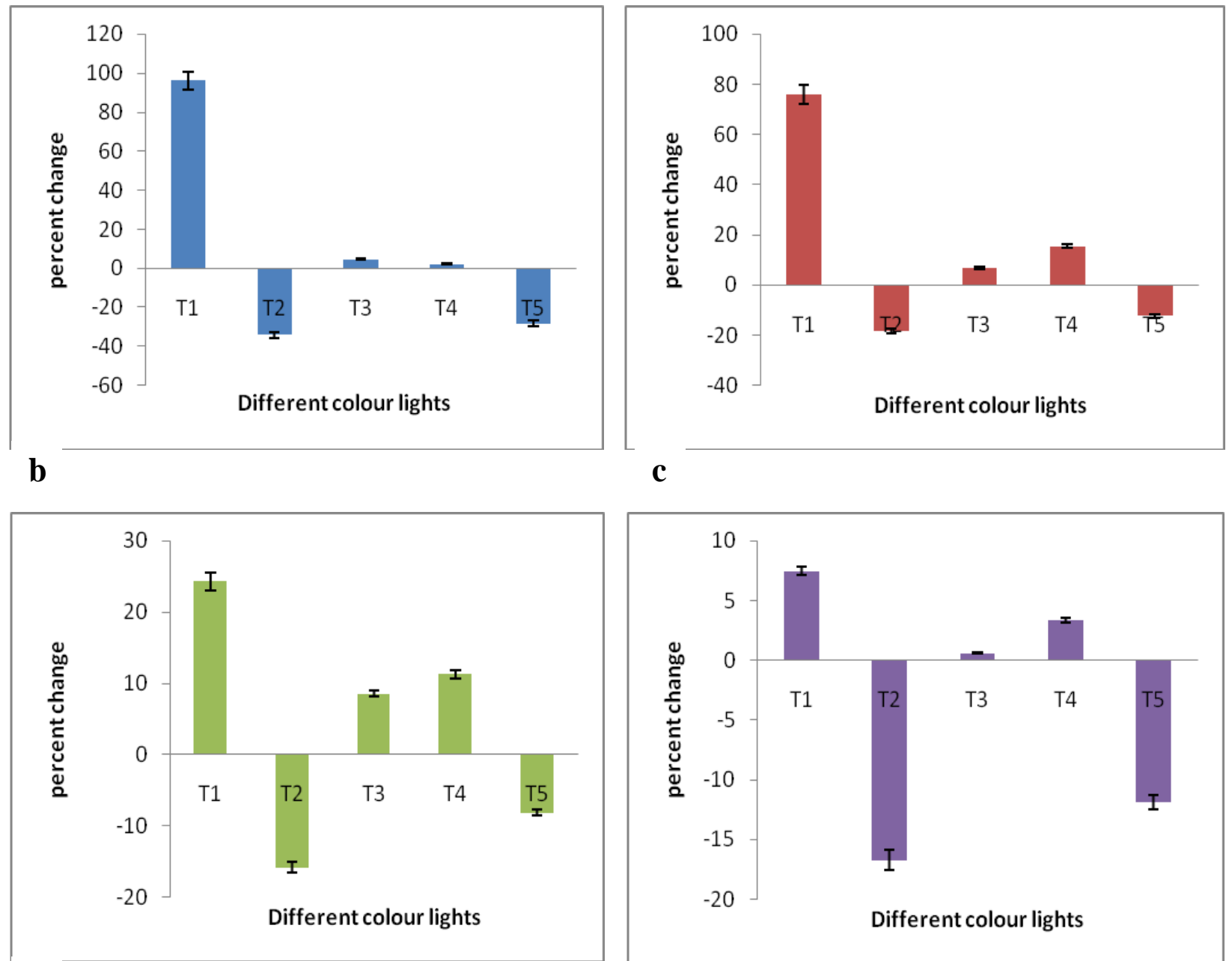

d

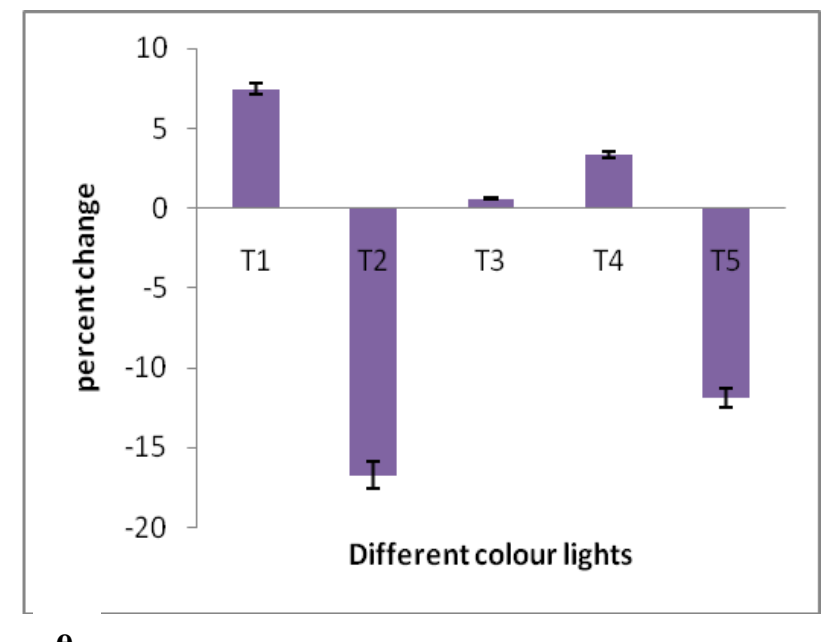

e

Figure.1: Percent change of a) $\mathrm{pH}, \mathrm{OC}, \mathrm{OM}, \mathrm{b}$ ) bacterial population, c) amylase activity, d) cellulase activity, e) invertase activity in the organic substrate in control and exposed to different colour lights. T1-Dark,T2-White,T3-Blue,T4-Green,T5-Red 
However, contradictory results have been reported by Kamel et al., (2016) who observed increase in bacterial count of $S$. aureus, $E$. coli and $P$. aeruginosa in laboratory conditions with exposure to noncoherent polarized white light relative to blue, red and green lights. Ashkenazi et al., (2003); Guffey and Willborn (2006) and Maclean et al., (2008) observed that many bacteria harbor sufficiently high concentration of endogenous photo-synthesizers which are destroyed by intensive irradiation with visible light especially by violet and blue light of wavelength $405 \mathrm{~nm}$ and $470 \mathrm{~nm}$. Kim et al., (2013) observed that irradiation at $625 \mathrm{~nm}$ (Red light) was not bactericidal to $S$. aureus, $E$. coli, and $P$. gingivalis, whereas wavelength of $425 \mathrm{~nm}$ (Blue) and $525 \mathrm{~nm}$ (Green) had deleterious effects. S. aureus was also killed at $525 \mathrm{~nm}$. Mueller et al., (2010) reported that inactive compounds like auto fluorescent proteins can absorb visible day light (500$700 \mathrm{~nm}$ ) and emit active electrons producing reactive oxygen species (ROS) leading to an increase in photo killing processes in bacteria. Lucca et al., (2012) reported that blue LED light $(470 \mathrm{~nm})$ effectively inhibits growth of bacteria and filamentous fungi.

In the present study, all the treatments were inoculated with the earthworm E. eugeniae and exposed to different coloured lights at low intensity. The variation in the bacterial population and enzyme activities was most likely due to the dual effects of light exposures and earthworm activities. The results also suggest that darkness provides the most favourable environment for maximal bacterial growth and white light exerts an inhibitory effect. The relatively high percent reduction in organic carbon in $\mathrm{T} 1$ with the highest population of bacteria and enzyme activities support this hypothesis. Other low intensity colour lights apparently do not influence the bacterial growth and exoenzyme excretion substantially in the organic substrate during the process of decomposition. The study thus indicated that bacterial population and exoenzyme activities in semidecomposed cattle dung are influenced by variation in light colours during vermicomposting but this variation was not significant. White light had the inhibitory effect on bacterial growth and enzyme excretion. Darkness provides the most favourable environment for maximal bacterial growth and exoenzyme activities in the organic substrate and consequent decomposition of organics.

\section{References}

Araújo, A. S., Leite, L. F., Santos, V. B., and Carneiro, R. F. (2009). Soil microbial activity in conventional and organic agricultural systems. Sustainability, 1(2), 268-276.

Ashkenazi, H., Malik, Z., Harth, Y., and Nitzan, Y. (2003). Eradication of Propionibacterium acnes by its endogenic porphyrins after illumination with high intensity blue light. FEMS Immunology and Medical Microbiology, 35(1), 17-24.

Fontana, C. R., Song, X., Polymeri, A., Goodson, J. M., Wang, X., and Soukos, N. S. (2015). The effect of blue light on periodontal biofilm growth in vitro. Lasers in medical science, 30(8), 2077-2086.

Guffey, J. S., and Wilborn, J. (2006). Effects of combined 405-nm and 880-nm light on Staphylococcus aureus and Pseudomonas aeruginosa in vitro. Photomedicine and Laser Therapy, 24(6), 680-683.

Kamel, H.K; Saeed, C.H and Hassan, N.I (2016). Comparative effect of different visible light energy on bacterial growth. Int J Adv Res., 4 (2), 263-270.

Kim, S., Kim, J., Lim, W., Jeon, S., Kim, O., Koh, J. T., and Kim, O. (2013). In vitro 
bactericidal effects of 625,525 , and 425 $\mathrm{nm}$ wavelength (red, green, and blue) light-emitting diode irradiation. Photomedicine and laser surgery, 31(11), 554-562.

Li, X., and Sarah, P. (2003). Enzyme activities along a climatic transect in the Judean Desert. Catena, 53(4), 349-363.

Liu, X-M., Qi, L., Liang, W. J., and Jiang, Y. (2008). Distribution of soil enzyme activities and microbial biomass along a latitudinal gradient in farmlands of Songliao Plain, Northeast China. Pedosphere, 18(4), 431-440.

Lucca, D. A. J., Carter- Wientjes, C., Williams, K. A., and Bhatnagar, D. (2012). Blue light (470 nm) effectively inhibits bacterial and fungal growth. Letters in applied microbiology, 55(6), 460-466.

Maclean, M., MacGregor, S. J., Anderson, J. G., and Woolsey, G. (2008). Highintensity narrow-spectrum light inactivation and wavelength sensitivity of Staphylococcus aureus. FEMS microbiology letters, 285(2), 227-232.

Mueller, G., Waldeck, W., and Braun, K. (2010). From green to red-To more dead? Autofluorescent proteins as photosensitizers. Journal of
Photochemistry and Photobiology B: Biology, 98(1), 95-98.

Parkinson, D., Gray, T.R.G. and S.T., William (1971). Methods to study ecology of soil microorganisms. IBP Handbook No. 19, Blackwell Scientific Publ. oxford. PP. 116.

Pavel, R., Doyle, J., and Steinberger, Y. (2004). Seasonal patterns of cellulase concentration in desert soil. Soil Biology and Biochemistry, 36(3), 549-554.

Ross, D.J. and Robert H.S. (1970). Enzyme activities and oxygen uptake of soil under pasture in temperature and rainfall sequence. J. Soil Sci., 21, 368381.

Shi, W., Dell, E., Bowman, D., and Iyyemperumal, K. (2006). Soil enzyme activities and organic matter composition in a turfgrass chronosequence. Plant and soil, 288(12), 285-296.

Todar, K. (2012). Bacillus anthracis and Anthrax. Todar's Online Textbook of Microbiology.

Walkley, A., and Black, I. A. (1934). An examination of the Degtjareff method for determining soil organic matter, and a proposed modification of the chromic acid titration method. Soil science, 37(1), 29-38.

\section{How to cite this article:}

Mishra, C.S.K., Debayana Priyadarsini and Suryasikha Samal. 2018. Microbial Population Dynamics and Exoenzyme Activities in Semidecomposed Organic Substrate Exposed to Low Intensity Colour Lights during Vermicomposting. Int.J.Curr.Microbiol.App.Sci. 7(11): 10271032. doi: https://doi.org/10.20546/ijcmas.2018.711.118 